\title{
Silver and palladium complexes of a bis(benzimidazolin-2-ylidene)pyridine pincer ligand
}

\author{
David H. Brown, ${ }^{*,}$ Gareth L. Nealon, ${ }^{\dagger}$ Peter V. Simpson, ${ }^{\ddagger}$ Brian W. Skelton ${ }^{\ddagger}$ and Zhisen Wang ${ }^{\dagger}$ \\ Nanochemistry Research Institute, Department of Applied Chemistry, Curtin University of Technology, \\ GPO Box U1987, Perth WA 6845, Australia, and Chemistry M313, School of Biomedical, \\ Biomolecular and Chemical Sciences, The University of Western Australia, Crawley, WA 6009, \\ Australia
}

*To whom correspondence should be addressed.E-mail: d.h.brown@curtin.edu.au. Tel: +61 89266 1279. Fax: +61 892664699.

${ }^{\dagger}$ Curtin University of Technology

* The University of Western Australia

Summary: Reaction of 2,6-bis(3-butylbenzimidazol-1-ium)pyridine dibromide with silver oxide affords a dinuclear complex of the type $\left[\mathrm{L}_{2} \mathrm{Ag}_{2}\right]^{2+} \quad[\mathrm{L}=2$,6-bis(3-butylbenzimidazolin-2ylidene)pyridine]. ${ }^{1} \mathrm{H}$ NMR spectroscopic studies suggest that the dinuclear structure is also present in solution. Transmetallation of the silver-NHC complex with $\mathrm{PdCl}_{2}\left(\mathrm{CH}_{3} \mathrm{CN}\right)_{2}$ yields a mononuclear palladium complex of the type $[\mathrm{LPdCl}]^{+}$, with a chelating $C, N, C$-pincer ligand. 
$\mathrm{N}$-Heterocyclic carbenes (NHCs) and their metal complexes are prevalent in modern organometallic chemistry. ${ }^{1}$ One of the main areas of investigation of these systems involves the use of NHCs as ligands in metal-center mediated catalytic reactions. ${ }^{2}$ Studies involving NHCs are, in general, dominated by NHCs based on the imidazole ring., ${ }^{3,4}$ Benzimidazolin-2-ylidenes have received considerably less interest though in recent years this area has been developed by a number of groups. ${ }^{5,6}$

One class of NHC ligands that has attracted significant attention to-date is that of the $C, N, C$ pyridine-based pincer-ligands (e.g. ligands in 1 and 2).,4 Within this class, the bis(imidazolinylidene)2,6-pyridine ligands (as in 1) have been extensively investigated with a wide range of transition metals (e.g. Cr, Fe, Ru, Rh, Pd, Ni, Ti). ${ }^{3}$ The complexes 1 and $\mathbf{2}$ have been of interest because of their application as pre-catalysts in coupling reactions. Complex $\mathbf{1}$ displays high activity in Heck reactions, including significant activity with the typically unreactive aryl chlorides. ${ }^{7,8}$ Complexes of benzimidazolin-2-ylidene $C, N, C$ pyridine-based pincer ligands are relatively unexplored and have, until recently, only been reported with a lutidinediyl structure (e.g. 3). ${ }^{9}$ During the study reported here, Dötz and co-workers reported the synthesis and catalytic activity of $\mathbf{4}$ - the first metal complex of a bis(benzimidazolin-2-ylidene)-pyridine pincer with a 2,6-pyridine core. ${ }^{10}$ 


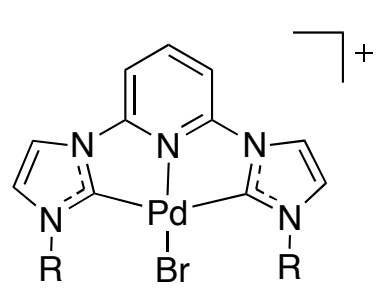

1

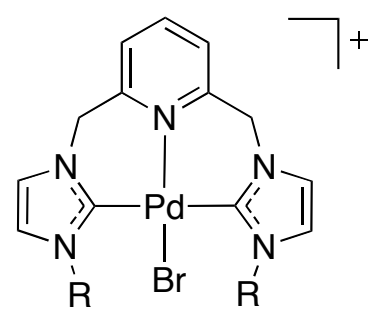

2<smiles></smiles>

3

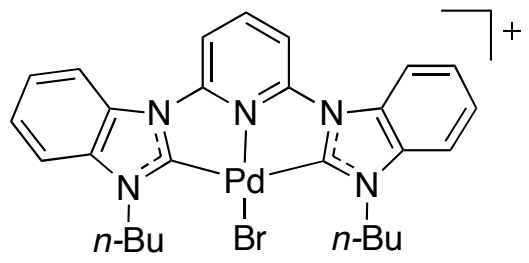

4

\section{Results and Discussion}

The benzimidazolium salt $5.2 \mathrm{Br}$ was prepared by the alkylation of 2,6di(benzimidazoyl)pyridine with excess 1-bromobutane in DMF. 2,6-Di(benzimidazoyl)pyridine was conveniently prepared by the reaction of sodium benzimidazolate with 2,6-dichloropyridine in DMF, initially at room temperature, then at $60{ }^{\circ} \mathrm{C}$ and finally heating at $140{ }^{\circ} \mathrm{C}$, without using a sealed reactor. See Supporting Information for the synthesis and characterization of $\mathbf{5 . 2 B r}$ and di(benzimidazoyl)pyridine, and some further discussion.

The reaction of 5.2Br with silver(I) oxide in methanol, followed by filtration (to remove $\mathrm{AgBr}$ ) and subsequent precipitation by the addition of a solution of sodium tetraphenylborate afforded the dinuclear silver complex $6.2 \mathrm{BPh}_{4}$ in $81 \%$ yield (Scheme 1). Precipitation with tetraphenylborate allows the facile isolation of $6.2 \mathrm{BPh}_{4}$. Attempts at isolating a product, such as $6.2 \mathrm{Br}$, directly from the reaction mixture was not successful. 
Scheme 1. Synthesis of 6.2BPh 4 and 7.BPh

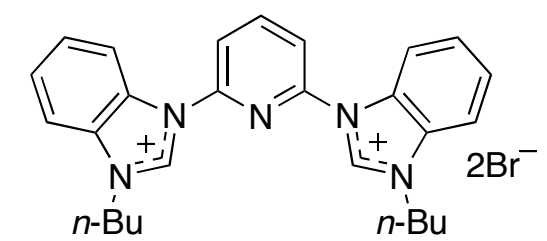

\subsection{Br}

(i) $\mathrm{Ag}_{2} \mathrm{O}, \mathrm{MeOH} \downarrow$ (ii) $\mathrm{NaBPh}_{4}$
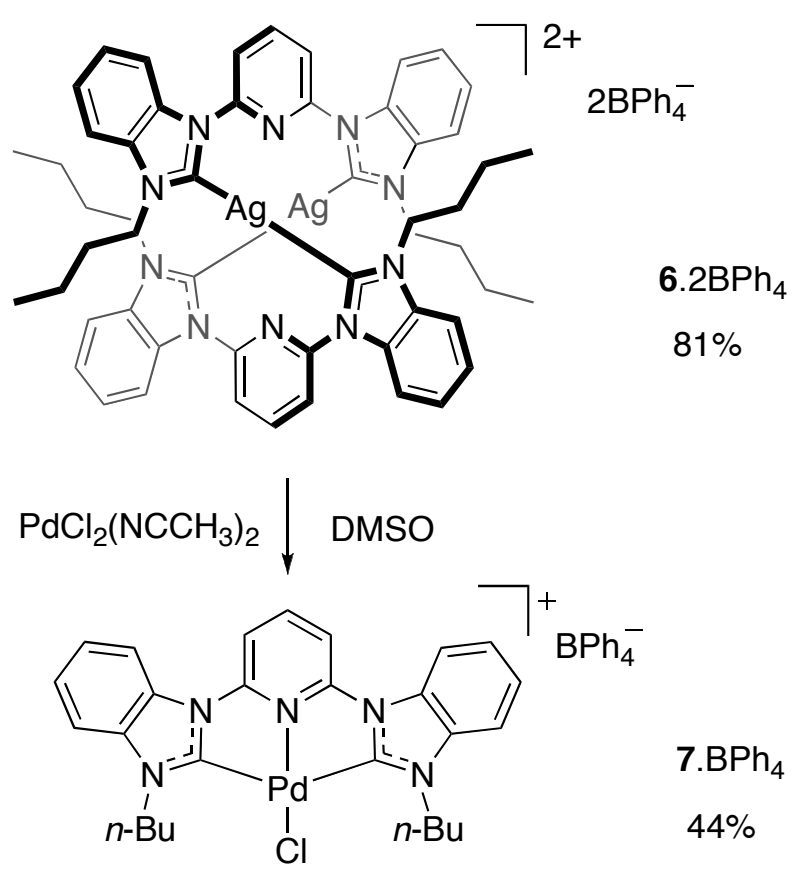

Single crystal X-ray crystallographic studies indicate that, in the solid-state, complex $\mathbf{6}$ exists as a dinuclear silver complex with the twisted structure shown in Scheme 1 (see Figure 1 and Solid-State studies). The ${ }^{13} \mathrm{C}$ NMR spectrum of a solution of $6.2 \mathrm{BPh}_{4}$ in $\mathrm{DMSO}-d_{6}$ displays a broad doublet centered at ca. $190 \mathrm{ppm}$ (splitting $200 \mathrm{~Hz}$ ), which is attributed to the carbene carbons bound to a silver center and is consistent with the literature. ${ }^{6,11}$ The ${ }^{1} \mathrm{H}$ NMR spectroscopic studies of solutions of 6.2BPh ${ }_{4}$ suggest that, at least with a tetraphenylborate counter-anion, the dinuclear structure is also present in solution. Of particular interest are the chemical shifts of the signals corresponding to the protons of the butyl chains. The chemical shifts of the signals corresponding to the methylene and 
methyl groups of the butyl chains on 6 ( $\delta 3.52,1.14,0.93$ and 0.54 ppm for $\mathrm{CH}_{2} \mathrm{CH}_{2} \mathrm{CH}_{2} \mathrm{CH}_{3}$, DMSO$d_{6}$ ) are significantly up-field compared to the analogous signals for either the ligand precursor 5 ( $\delta$ $4.71,2.05,1.48$ and $\left.1.02 \mathrm{ppm}, \mathrm{DMSO}-d_{6}\right)$ or the palladium complex $7(\delta 4.80,1.81,1.41$ and 0.91 ppm, DMSO- $\left.d_{6}\right)$. The solid-state structure of $\mathbf{6}$ reveals that the butyl chains are in a position such that they could be affected by magnetic shielding from the aromatic groups (pyridyl, benzo or imidazolyl) of the opposing ligand in the dinuclear structure [e.g. see $\mathrm{C}(8)$ in Figure 2]. Such shielding would cause an up-field shift of signals in the ${ }^{1} \mathrm{H}$ NMR spectrum, suggesting that the dinuclear structure of 6 identified in the solid-state is also present in solution.

During the isolation of $6.2 \mathrm{BPh}_{4}$ a small quantity of crystals was isolated from the methanolic filtrate, which were identified as the hydrolysis product $8 \cdot \mathrm{BPh}_{4}\left({ }^{1} \mathrm{H} \mathrm{NMR}\right.$ spectroscopic and $\mathrm{X}$-ray crystallographic studies). Hydrolysis of benzimidazolium cations to afford formanilides (or acetanilides in the case of 2-methylbenzimidazolium cations) has been previously reported in the literature. ${ }^{12}$ The formation of the hydrolysis product $\mathbf{8}$ could be avoided by adding $3 \AA$ molecular sieves to the reaction of 5.2Br with $\mathrm{Ag}_{2} \mathrm{O}$ in methanol.

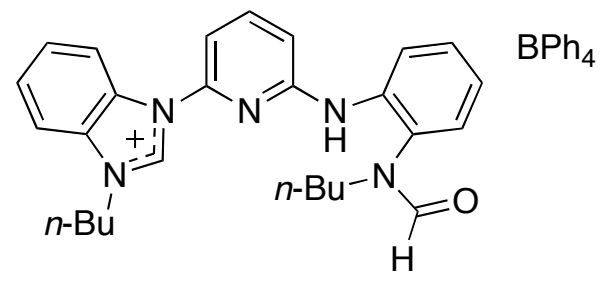

8. $\mathrm{BPh}_{4}$

Following the route to Pd-NHC complexes via Ag-NHC transmetallation, ${ }^{13}$ the reaction of the dinuclear silver complex $6.2 \mathrm{BPh}_{4}$ with $\mathrm{PdCl}_{2}\left(\mathrm{CH}_{3} \mathrm{CN}\right)_{2}$ in DMSO at room temperature afforded the mononuclear palladium complex 7, which was isolated as the tetraphenylborate salt $7 . \mathrm{BPh}_{4}$ in a $44 \%$ yield. The use of other solvents (DMF, acetonitrile, dichloromethane) was unsuccessful. The salt 
7. $\mathrm{BPh}_{4}$ is soluble in organic solvents, presumably aided by the lipophilic counter-anion, and can be readily recrystallised from acetone. The mononuclear structure of 7 was confirmed by crystallographic studies (see Figure 3 and Solid-State studies) and the ${ }^{1} \mathrm{H}$ NMR spectra of solutions of 7.BPh ${ }_{4}$ are consistent with the structure shown.

In the present study, initial attempts to prepare a palladium complex from $\mathbf{5}$ had focused on the reaction of 5.2Br with $\mathrm{Pd}(\mathrm{OAc})_{2}$ in $\mathrm{DMF}$ or DMSO under thermal conditions. At low temperatures (60 $\left.{ }^{\circ} \mathrm{C}\right)$ in DMF the reaction was slow. Moreover, at high temperatures $\left(>150{ }^{\circ} \mathrm{C}\right)$ and prolonged reaction times only complex mixtures were isolated, displaying numerous broad signals in their ${ }^{1} \mathrm{H}$ NMR spectra. Dötz and co-workers reported the synthesis of $4 . \mathrm{Br}$ by reacting $5.2 \mathrm{Br}$ with $\mathrm{Pd}(\mathrm{OAc})_{2}$ in $\mathrm{DMSO}$ at $160{ }^{\circ} \mathrm{C}$ in a microwave reactor for only $25 \mathrm{~min} .{ }^{10}$ Using similar reaction conditions $(5.2 \mathrm{Br}$ with $\mathrm{Pd}(\mathrm{OAc})_{2}$ in $\left.\mathrm{DMSO}, 25 \mathrm{~min}, 160^{\circ} \mathrm{C}\right)$ but in the absence of microwave radiation was only somewhat more successful, though significant broad signals in the spectrum indicated the formation of species other than 4.Br. These results would suggest the success of the method reported by Dötz and coworkers depends largely on the use of microwave radiation. The fact that the prolonged reaction times did not afford appreciable quantities of $\mathbf{4}$ may also indicate that the benzimidazolin-2-ylidene-pincer palladium complexes (e.g. $4 . \mathrm{Br}$ and $\mathbf{7 .}\left(\mathrm{BPh}_{4}\right.$ ) may not be as stable as their imidazolin-2-ylidene analogues (e.g. $1 \mathrm{R}=\mathrm{Me}, \mathrm{Bu})^{7,8}$ To further investigate the stability of $7 . \mathrm{BPh}_{4}$, a solution of the complex in DMSO- $d_{6}$ was heated at $160{ }^{\circ} \mathrm{C}$ in a sealed flask for 1 day. Analysis of the solution by ${ }^{1} \mathrm{H}$ NMR spectroscopy indicated the presence of additional species (additional sharp and broad signals), though the majority of the complex was still intact, indicating some decomposition had occurred.

Mass spectroscopic studies (low resolution FAB) were conducted on $6.2 \mathrm{BPh}_{4}$ and $7 . \mathrm{BPh}_{4}$. For 7. $\mathrm{BPh}_{4}$, an ion cluster centered near $\mathrm{m} / z .565$ is consistent with the mononuclear complex cation 7 (e.g. 564, $\left.\left[\mathrm{L}^{106} \mathrm{Pd}^{35} \mathrm{Cl}\right]^{+}, 566,\left[\mathrm{~L}^{108} \mathrm{Pd}^{35} \mathrm{Cl}\right]^{+}\right)$. In the case of the dinuclear silver complex $6.2 \mathrm{BPh}{ }_{4}$ the spectrum displayed two ion clusters, centered at $\mathrm{m} / \mathrm{z} 1063$ and 531, which are consistent with the dinuclear cation 
plus a hydride (e.g. 1063, $\left[\mathrm{L}_{2}{ }^{107} \mathrm{Ag}{ }^{109} \mathrm{Ag}+\mathrm{H}^{-}\right]^{+}$) and a fragment species (e.g. 530, $\left[\mathrm{L}^{107} \mathrm{Ag}\right]^{+}$; and 532 $\left.\left[\mathrm{L}^{109} \mathrm{Ag}\right]^{+}\right)$.

Solid-state studies: The cation of $\mathbf{6}$ is shown in Figure 1 (see also Supporting Information) and consists of a $\left[\mathrm{Ag}_{2} \mathrm{~L}_{2}\right]^{2+}$ dimer situated on a crystallographic inversion center with the benzimidazolin-2ylidene groups of each ligand coordinated to two different Ag atoms. The coordination about the Ag atom is essentially linear with the angles around the $\mathrm{Ag}$ atoms, $\mathrm{C}(12)-\mathrm{Ag}(1)-\mathrm{C}\left(32^{\prime}\right) 176.63(6)^{\circ}\left({ }^{\prime}\right.$ refers to the centrosymmetrically related atom at $-\mathrm{x},-\mathrm{y}, 1-\mathrm{z})$. The $\mathrm{Ag}$...Ag' distance is $3.7848(2) \AA$. The angles between the planes of the pendant groups and the central pyridine of the ligand are 42.57(4) and $39.91(4)^{\circ}$. The Ag to pyridyl nitrogen distances in $6\left[\operatorname{Ag}(1)-\mathrm{N}(21), \mathrm{N}\left(21^{\prime}\right) 2.984(1), 3.012(1) \AA ̊\right.$ are sufficiently long as to indicate only a weak interaction. The structure of $\mathbf{6}$ is similar to that of the imidazolin-2-ylidene complex $\mathbf{9}$, though in 9 the $\mathrm{C}$ - $\mathrm{Ag}-\mathrm{C}$ angles are even more distorted from linearity at $165.5(2)^{\circ}$, the $\mathrm{Ag} \ldots \mathrm{Ag}$ distance is much shorter $(3.1585(6) \AA)$, but the ligands are much less twisted with central/pendant ring interplanar angles of $21.3(2)$ and $20.6(3)^{\circ}$ for the two ligands..$^{14}$ 


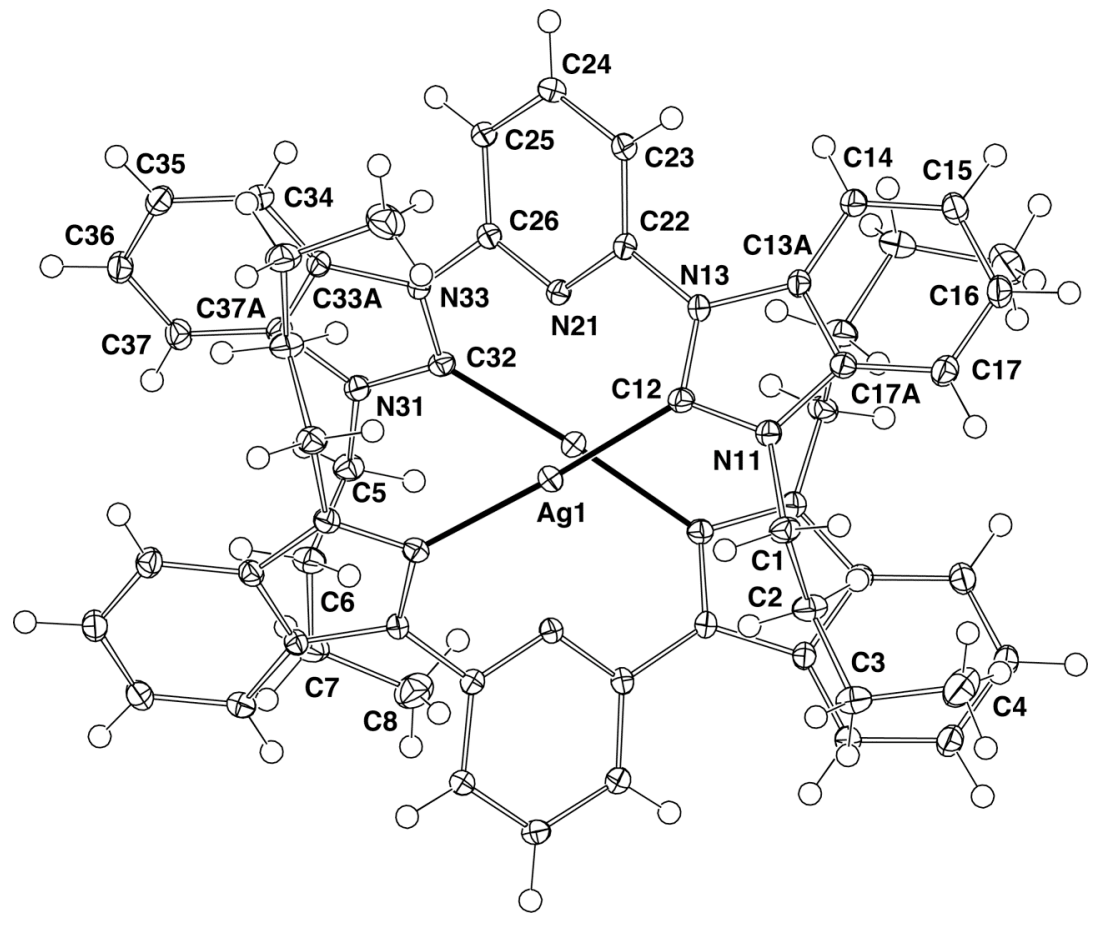

Figure 1. Molecular structure of the cation 6, projected oblique to the Ag-Ag vector. Ellipsoids have been drawn at the 50\% probability level. Selected bond lengths $(\AA)$ and angles (deg): $\operatorname{Ag}(1)-C(12)$ 2.092(1), C(12)- $\mathrm{Ag}(1)-\mathrm{C}(32 ') 176.63(6)$ (' refers to the atom at $-\mathrm{x},-\mathrm{y}, 1-\mathrm{z})$.

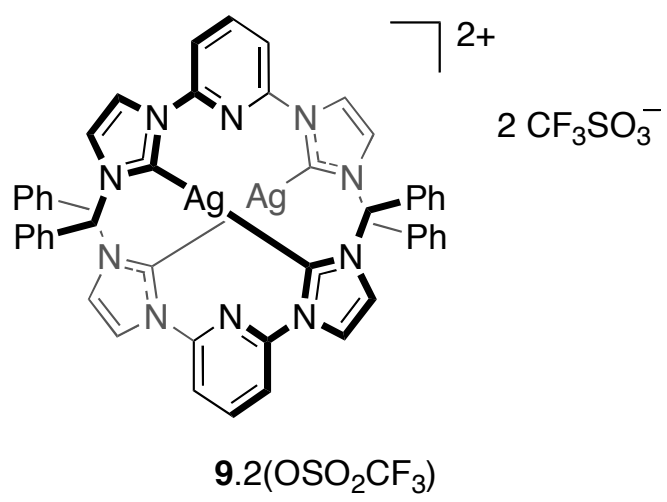

The structure of the cation of $\mathbf{7}$ has a distorted square planar coordination around the central $\mathrm{Pd}$ atom (Figure 2). Except for the butyl chains, the atoms are remarkably coplanar with interplanar angles between the pyridyl and the two pendant rings now $5.73(5)$ and $3.11(6)^{\circ}$ and the angle between the 2 pendant rings being $2.68(5)^{\circ}$. This geometry is very similar to that found in the bromo-imidazoyl-2- 
ylidene analogues $1 . \mathrm{Br}(\mathrm{R}=\mathrm{Me}, \mathrm{Bu}))^{7,8,15}$ The butyl groups of $\mathbf{7}$ are directed out of, and are cis relative to, the coordination plane. This allows pairing of the cations resulting in a short Pd...Pd distance of 3.6105(2) $\AA$ similar to that seen in 1.Br $(\mathrm{R}=\mathrm{Bu})$ of 3.511(18) $\AA^{8}{ }^{8}$

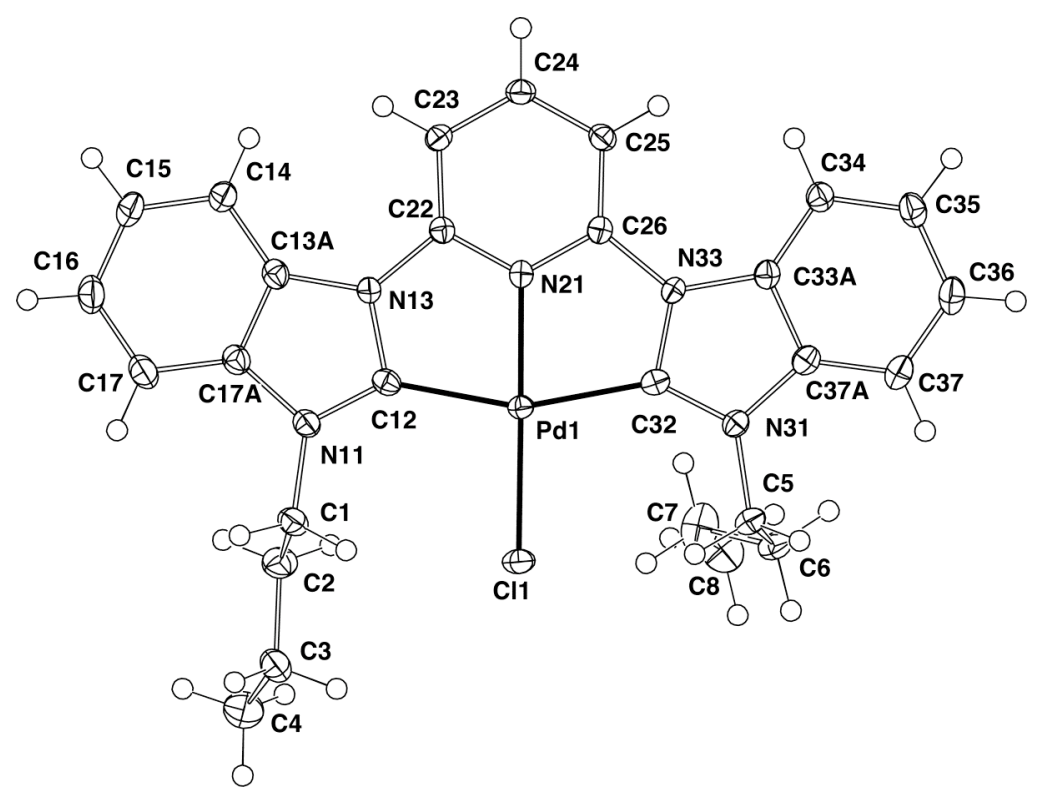

Figure 2. Molecular structure of the cation 7 projected onto the coordination plane. Ellipsoids have been drawn at the $50 \%$ probability level. Selected bond lengths $(\AA)$ and angles $(\operatorname{deg})$ : $\operatorname{Pd}(1)-\mathrm{N}(21)$ 1.9701(15), $\mathrm{Pd}(1)-\mathrm{C}(12)$ 2.0202(18), $\mathrm{Pd}(1)-\mathrm{C}(32)$ 2.0280(18), $\mathrm{Pd}(1)-\mathrm{Cl}(1)$ 2.2874(5), $\mathrm{Pd}(1) \ldots \mathrm{Pd}\left(1^{\prime}\right)$ $3.6105(2)$ (' refers to the atom at 1-x,1-y,1-z), N(21)-Pd(1)-C(12) 79.67(7), N(21)-Pd(1)-C(32) 79.29(6), C(12)-Pd(1)-C(32) 158.94(7), N(21)-Pd(1)-Cl(1) 179.42(4), C(12)-Pd(1)-Cl(1) 99.77(5), $\mathrm{C}(32)-\mathrm{Pd}(1)-\mathrm{Cl}(1) 101.27(5)$.

\section{Conclusion}

We have reported the synthesis of a dinuclear bis(benzimidazolin-2-ylidene)-2,6-pyridine-silver complex, of the type $\left[\mathrm{L}_{2} \mathrm{Ag}_{2}\right]^{2+}$. ${ }^{1} \mathrm{H}$ NMR spectroscopic studies suggest that the dinuclear structure identified in the solid-state by X-ray crystallography, was also present in solution. Silver-NHC transmetallation with a palladium(II) source afforded a bis(benzimidazolin-2-ylidene)-2,6-pyridinepalladium complex. An alternative and convenient synthesis of di(benzimidazolyl)-2,6-pyridine is 
reported, which avoids the use of a sealed reaction system.

\section{Experimental}

General Methods. Nuclear magnetic resonance spectra were recorded using Varian Gemini 200 (200 $\mathrm{MHz}$ for ${ }^{1} \mathrm{H}, 50 \mathrm{MHz}$ for $\left.{ }^{13} \mathrm{C}\right)$, Bruker Avance $500\left(500.1 \mathrm{MHz}\right.$ for ${ }^{1} \mathrm{H}, 125.8 \mathrm{MHz}$ for $\left.{ }^{13} \mathrm{C}\right)$ or Bruker AV-600 MHz (600.13 MHz for ${ }^{1} \mathrm{H}, 150.90 \mathrm{MHz}$ for ${ }^{13} \mathrm{C}$ ) spectrometers at ambient temperature. ${ }^{1} \mathrm{H}$ and

${ }^{13} \mathrm{C}$ chemical shifts were referenced to residual solvent resonances. Microanalyses were performed by the Central Science Laboratory at the University of Tasmania. Mass spectra were obtained by Dr A. Reeder (The University of Western Australia) using a VG Autospec Mass Spectrometer via fast atom bombardment (FAB) with a cesium ion source and a m-nitrobenzyl alcohol matrix. DMF was dried over $4 \AA$ molecular sieves and methanol over $3 \AA$ molecular sieves.

Silver complex 6.2BPh 4 . A mixture of $\mathrm{Ag}_{2} \mathrm{O}(0.67 \mathrm{~g}, 2.89 \mathrm{mmol})$ and $\mathbf{5 . 2 B r}(1 \mathrm{~g}, 1.71 \mathrm{mmol})$ in anhydrous methanol $(50 \mathrm{~mL})$ was stirred at room temperature, under nitrogen, in the absence of light for $2 \mathrm{~d}$. The mixture was filtered through Celite. A solution of sodium tetraphenylborate $(2.3 \mathrm{~g}, 6.73$ $\mathrm{mmol})$ in anhydrous methanol $(20 \mathrm{~mL})$ was added to the filtrate. The resulting pink precipitate was collected, washed with hot methanol and recrystallised from hot acetonitrile to afford colourless crystals $(1.11 \mathrm{~g}, 81 \%)$. Crystals suitable for X-ray diffraction studies were grown by the slow evaporation of an acetonitrile solution of $6.2 \mathrm{BPh}_{4}$. See Supporting Information for ${ }^{1} \mathrm{H}$ and ${ }^{13} \mathrm{C}$ NMR data. $\mathrm{MS}(\mathrm{FAB}+): m / z=1063\left[\mathrm{M}-2 \mathrm{BPh}_{4}+\mathrm{H}^{-}\right]^{+}\left(\mathrm{C}_{54} \mathrm{H}_{59} \mathrm{~N}_{10}{ }^{107} \mathrm{Ag}^{109} \mathrm{Ag}\right), 530\left(\mathrm{C}_{27} \mathrm{H}_{29} \mathrm{~N}_{5}{ }^{107} \mathrm{Ag}\right), 532$ $\left(\mathrm{C}_{27} \mathrm{H}_{29} \mathrm{~N}_{5}{ }^{107} \mathrm{Ag}\right)$. Anal. Calcd for $\mathrm{C}_{102} \mathrm{H}_{98} \mathrm{Ag}_{2} \mathrm{~B}_{2} \mathrm{~N}_{10}$ : C, 72.01; H, 5.81; N, 8.23. Found: C, 71.78; H, $5.81 ; \mathrm{N}, 8.14$.

During the synthesis of $6.2 \mathrm{BPh}_{4}$ the hydrolysis product $\mathbf{8} . \mathrm{BPh}_{4}$ crystallised from the filtrate of the hot methanol wash. See Supporting Information for compound characterization data and crystallographic data. 


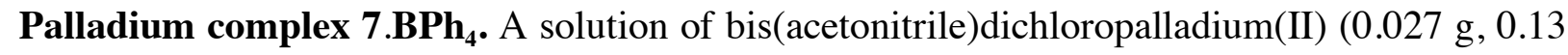
mmol) in DMSO $(5 \mathrm{~mL})$ was added to a solution of $6.2 \mathrm{BPh}_{4}(0.1 \mathrm{~g}, 0.06 \mathrm{mmol})$ in DMSO $(10 \mathrm{~mL})$ which was then stirred at room temperature, under nitrogen, in the absence of light for $12 \mathrm{~h}$. The mixture was filtered through Celite and the filtrate was concentrated under reduced pressure. The black oily residue was dissolved in hot acetone $(20 \mathrm{~mL})$ and filtered through Celite to afford a clear dark brown solution. Slow evaporation of the acetone solution afforded white crystals and a fine black solid. The solids were collected, washed with cold acetone $(3 \times 5 \mathrm{~mL})$ and recrystallised from hot acetone to afford light yellow crystals (53 mg, 44\%). Crystals suitable for X-ray diffraction studies were grown by the slow evaporation of a solution of the complex in acetone. See Supporting Information for ${ }^{1} \mathrm{H}$ and ${ }^{13} \mathrm{C}$ NMR data. MS (FAB+): $m / z=564 \quad\left[\mathrm{M}-\mathrm{BPh}_{4}\right]^{+}\left(\mathrm{C}_{27} \mathrm{H}_{29} \mathrm{~N}_{5}{ }^{106} \mathrm{Pd}^{35} \mathrm{Cl}\right), 566 \quad\left[\mathrm{M}-\mathrm{BPh}_{4}\right]^{+}$ $\left(\mathrm{C}_{27} \mathrm{H}_{29} \mathrm{~N}_{5}{ }^{108} \mathrm{Pd}{ }^{35} \mathrm{Cl}\right)$. Anal. Calcd for $\mathrm{C}_{51} \mathrm{H}_{49} \mathrm{BClN}_{5} \mathrm{Pd} .2 \mathrm{C}_{3} \mathrm{H}_{6} \mathrm{O}: \mathrm{C}, 68.41 ; \mathrm{H}, 6.14 ; \mathrm{N}, 7.00$. Found: $\mathrm{C}$, $68.08 ; \mathrm{H}, 6.01 ; \mathrm{N}, 7.00$.

X-ray Structure Determinations. The crystal data for $6.2 \mathrm{BPh}_{4}$ and $7 . \mathrm{BPh}_{4} \cdot 2$ acetone are summarized below with the structures depicted in Figures 1 and 2 . The crystal data for $5.2 \mathrm{Br}$ and 8. $\mathrm{BPh}_{4}$ and figures of the structures are provided in Supporting Information. In all figures ellipsoids have been drawn at the 50\% probability level. Crystallographic data for the structures were collected at 100(2) $\mathrm{K}$ on an Oxford Diffraction Xcalibur $\left(\mathbf{8} . \mathrm{BPh}_{4}\right)$ or Gemini $\left(5.2 \mathrm{Br}, 6.2 \mathrm{BPh}_{4}, 7 . \mathrm{BPh}_{4}\right.$.2acetone) diffractometer fitted with graphite-monochromated Mo $\mathrm{K} \alpha$ radiation yielding $N_{\text {total }}$ reflections, these merging to $N$ unique after multiscan absorption correction $\left(R_{\text {int }}\right.$ cited $)$, with $N_{\mathrm{o}}$ reflections with $I>3 \sigma(I)$. The structures were refined against $F^{2}$ with full-matrix least-squares using the program SHELXL-97. ${ }^{16}$ All $\mathrm{H}$-atoms were added at calculated positions and refined by use of a riding model with isotropic displacement parameters based on the isotropic displacement parameter of the parent atom. Anisotropic displacement parameters were employed throughout for the non-hydrogen atoms. For $\mathbf{9} \cdot \mathrm{BPh}_{4}$, the crystal was mounted on a fibre and transferred to the diffractometer at $c a .-15{ }^{\circ} \mathrm{C}$ to minimise any 
possible loss of solvent. Although no solvent was located in the structure, voids of $c a$. $40 \AA^{3}$ were located in the lattice. Attempts to effectively remove any electron density associated with these voids using the program Squeeze ${ }^{17}$ did not improve the model. The structure of $7 . \mathrm{BPh}_{4} \cdot 2$ acetone contains two molecules of acetone solvent per molecule of cation. The atoms of one of the molecules of acetone are disordered over two sites, with each component assigned occupancy factors of 0.5 after trial refinement. Their geometries were restrained to ideal values. CCDC 710306 - 710309 contain the supplementary crystallographic data for this paper. These data can be obtained free of charge from The Cambridge Crystallographic Data Centre via www.ccdc.cam.ac.uk/data_request/cif.

Crystallographic data: 6.2BPh $: \mathrm{C}_{102} \mathrm{H}_{98} \mathrm{Ag}_{2} \mathrm{~B}_{2} \mathrm{~N}_{10}, M=1701.26$, monoclinic, space group $I 2 / a$, a = $24.0034(13) \AA, \mathrm{b}=17.3322(5) \AA, \mathrm{c}=20.4685(7) \AA, \beta=104.162(4)^{\circ}, V=8256.7(6) \AA^{3}, Z=4, D=$ $1.369 \mathrm{Mg} \mathrm{m}^{-3}, \mu=0.531 \mathrm{~mm}^{-1}, T_{\max / \min }=1 / 0.810$, Crystal dimensions $0.41 \times 0.33 \times 0.30 \mathrm{~mm}, \theta_{\max }=$ $34.88^{\circ}, N_{\text {total }}=61107, N=17061, R_{\text {int }}=0.0429, N_{\mathrm{o}}=12189$, Data/restraints/parameters: $17061 / 0 / 525$, $R_{1}, w R_{2}[I>2 \sigma(I)]=0.0377,0.0928, R_{1}, w R_{2}$ [all data] $=0.0624,0.1006$, Goodness-of-fit 0.957, Largest peak, hole $\left(\mathrm{e} . \AA^{-3}\right)$ 2.022, -0.461. 7. $\mathrm{BPh}_{4}$.2acetone: $\mathrm{C}_{57} \mathrm{H}_{61} \mathrm{BClN}_{5} \mathrm{O}_{2} \mathrm{Pd}, M=1000.77$, monoclinic, space group $P 2_{1} / n, a=16.2612(3) \AA, b=14.0076(2) \AA, c=22.0855(8) \AA, \beta=99.021(3)^{\circ}, V=4968.4(2) \AA^{3}$, $Z=4, D=1.338 \mathrm{Mg} \mathrm{m} \mathrm{m}^{-3}, \mu=0.475 \mathrm{~mm}^{-1}, T_{\max / \min }=0.941 / 0.871$, Crystal dimensions $0.432 \times 0.357 \times 0.142 \mathrm{~mm}, \theta_{\max }=32.79^{\circ}, N_{\text {total }}=66261, N=17547, R_{\text {int }}=0.0508, N_{\mathrm{o}}=12006$, Data/restraints/parameters: $17547 / 8 / 642, R_{l}, w R_{2}[I>2 \sigma(I)]=0.0419,0.0905, R_{1}, w R_{2}$ [all data] $=$ 0.0724, 0.097, Goodness-of-fit 0.93, Largest peak, hole $\left(\mathrm{e} . \AA^{-3}\right) 1.022,-0.414$.

Acknowledgement. We thank Curtin University of Technology for a Research and Teaching Fellowship (to D.H.B.). 
Supporting Information Available: Synthesis and characterization details for 2,6di(benzimidazolyl)pyridine and $5.2 \mathrm{Br} ;{ }^{1} \mathrm{H}$ and ${ }^{13} \mathrm{C} \mathrm{NMR}$ data for $6.2 \mathrm{BPh}_{4}$ and $7 . \mathrm{BPh}_{4}$; compound characterization data for $\mathbf{8 .} \mathrm{BPh}_{4}$; figures, refinement data and discussion of the solid-state structures of 5.2Br, and $\mathbf{8 .} \mathrm{BPh}_{4}$; additional projection of the solid-state structure of cation $\mathbf{6}$; and cif files for $\mathbf{5 . 2 B r}$, 6.2BPh, $7 . \mathrm{BPh}_{4} \cdot 2$ acetone and $\mathbf{8} . \mathrm{BPh}_{4}$. This material is available free of charge via the Internet at http://pubs.acs.org.

\section{References}

(1) Hahn, F. E.; Jahnke, M. C., Angew. Chem. Int. Ed. 2008, 47, 3122.

(2) (a) Nolan, S. P., N-Heterocyclic carbenes in synthesis. Wiley-VCH: Weinheim, 2006; (b) Normand, A. T.; Cavell, K. J., Eur. J. Inorg. Chem. 2008, 2781; (c) Kantchev, E. A. B.; O'Brien, C. J.; Organ, M. G., Angew. Chem. Int. Ed. 2007, 46, 2768.

(3) Pugh, D.; Danopoulos, A. A., Coord. Chem. Rev. 2007, 251, 610.

(4) Peris, E.; Crabtree, R. H., Coord. Chem. Rev. 2004, 248, 2239.

(5) (a) Hahn, F. E.; Foth, M., J. Organomet. Chem. 1999, 585, 241; (b) Hahn, F. E.; Langenhahn, V.; Lügger, T.; Pape, T.; Le Van, D., Angew. Chem. Int. Ed. 2005, 44, 3759; (c) Huynh, H. V.; Han, Y.; Ho, J. H. H.; Tan, G. K., Organometallics 2006, 25, 3267; (d) Huynh, H. V.; Neo, T. C.; Tan, G. K., Organometallics 2006, 25, 1298; (e) Huynh, H. V.; Holtgrewe, C.; Pape, T.; Koh, L. L.; Hahn, E., Organometallics 2006, 25, 245; (f) Han, Y.; Huynh, H. V.; Koh, L. L., J. Organomet. Chem. 2007, 692, 3606; (g) Huynh, H. V.; Wong, L. R.; Ng, P. S., Organometallics 2008, 27, 2231; (h) Boydston, A. J.; Williams, K. A.; Bielawski, C. W., J. Am. Chem. Soc. 2005, 127, 12496; (i) Boydston, A. J.; Rice, J. D.; Sanderson, M. D.; Dykhno, O. L.; Bielawski, C. W., 
Organometallics 2006, 25, 6087; (j) Khramov, D. M.; Boydston, A. J.; Bielawski, C. W., Angew. Chem. Int. Ed. 2006, 45, 6186.

(6) Hahn, F. E.; Jahnke, M. C.; Pape, T., Organometallics 2006, 25, 5927.

(7) Peris, E.; Loch, J. A.; Mata, J.; Crabtree, R. H., Chem. Commun. 2001, 201.

(8) Loch, J. A.; Albrecht, M.; Peris, E.; Mata, J.; Faller, J. W.; Crabtree, R. H., Organometallics 2002, 21, 700 .

(9) (a) Hahn, F. E.; Jahnke, M. C.; Gomez-Benitez, V.; Morales-Morales, D.; Pape, T., Organometallics 2005, 24, 6458; (b) Jahnke, M. C.; Pape, T.; Hahn, F. E., Z. Naturforsch. B 2007, $62,357$.

(10) Tu, T.; Malineni, J.; Dötz, K. H., Adv. Synth. Catal. 2008, 350, 1791.

(11) (a) Wang, H. M. J.; Lin, I. J. B., Organometallics 1998, 17, 972; (b) Liu, Q.-X.; Yin, L.-N.; Wu, X.-M.; Feng, J.-C.; Guo, J.-H.; Song, H.-B., Polyhedron 2008, 27, 87; (c) Han, Y.; Hong, Y.-T.; Huynh, H. V., J. Organomet. Chem. 2008, 693, 3159.

(12) (a) Smith, C. W.; Rasmussen, R. S.; Ballard, S. A., J. Am. Chem. Soc. 1949, 71, 1082; (b) Hausner, S. H.; Striley, C. A. F.; Krause-Bauer, J. A.; Zimmer, H., J. Org. Chem. 2005, 70, 5804; (c) Kolodyanzhnaya, S. N.; Simonov, A. M.; Kolodyazhnyi, Y. V.; Osipov, O. A.; Bren, V. A.; Sadekov, I. D., Chem. Heterocycl. Compd. Engl. Transl. 1970, 6, 224; (d) Simonov, A. M.; Vitkevich, N. D., Zh. Obshch. Khim. 1959, 29, 2404 CAN 54:50389; (e) Garnovskii, A. D.; Simonov, A. M.; Minik, V. I.; Dionis'ev, V. D., Zh. Obshch. Khim. 1964, 34, 272.

(13) (a) Lin, I. J. B.; Vasam, C. S., Coord. Chem. Rev. 2007, 251, 642; (b) Garrison, J. C.; Youngs, W. J., Chem. Rev. 2005, 105, 3978.

(14) Caballero, A.; Díez-Barra, E.; Jalón, F. A.; Merino, S.; Rodríguez, A. M.; Tejeda, J., J. Organomet. Chem. 2001, 627, 263. 
(15) 1.Br: $\mathrm{R}=\mathrm{Bu}, \mathrm{C}-\mathrm{Pd}-\mathrm{C} 158.7(4)^{\circ}, \mathrm{N}-\mathrm{Pd}-\mathrm{Cl} 177.0(2)^{\circ}$; central/pendant interplanar angles $2.7(5)$ and 3.7(5) ${ }^{\circ} ; \mathrm{R}=\mathrm{Me}, \mathrm{C}-\mathrm{Pd}-\mathrm{C} 158.5(2), \mathrm{N}-\mathrm{Pd}-\mathrm{Cl} 179.0(1)^{\circ}$, central/pendant interplanar angles 1.6(2) and $1.4(2)^{\circ}$.

(16) Sheldrick, G. M., Acta Crystallogr., Sect. A 2008, 64, 112.

(17) van der Sluis, P.; Spek, A. L., Acta Crystallogr., Sect. A 1990, 46, 194. 


\section{Figures}

Scheme 1. Synthesis of $6.2 \mathrm{BPh}_{4}$ and 7.BPh

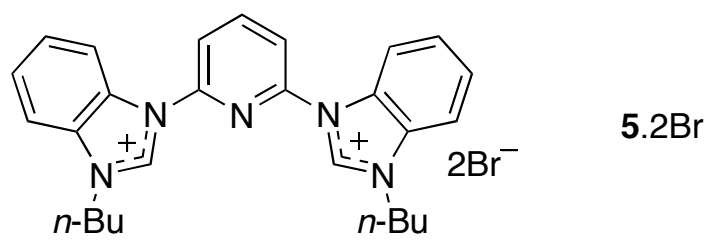

(i) $\mathrm{Ag}_{2} \mathrm{O}, \mathrm{MeOH} \downarrow$ (ii) $\mathrm{NaBPh}_{4}$
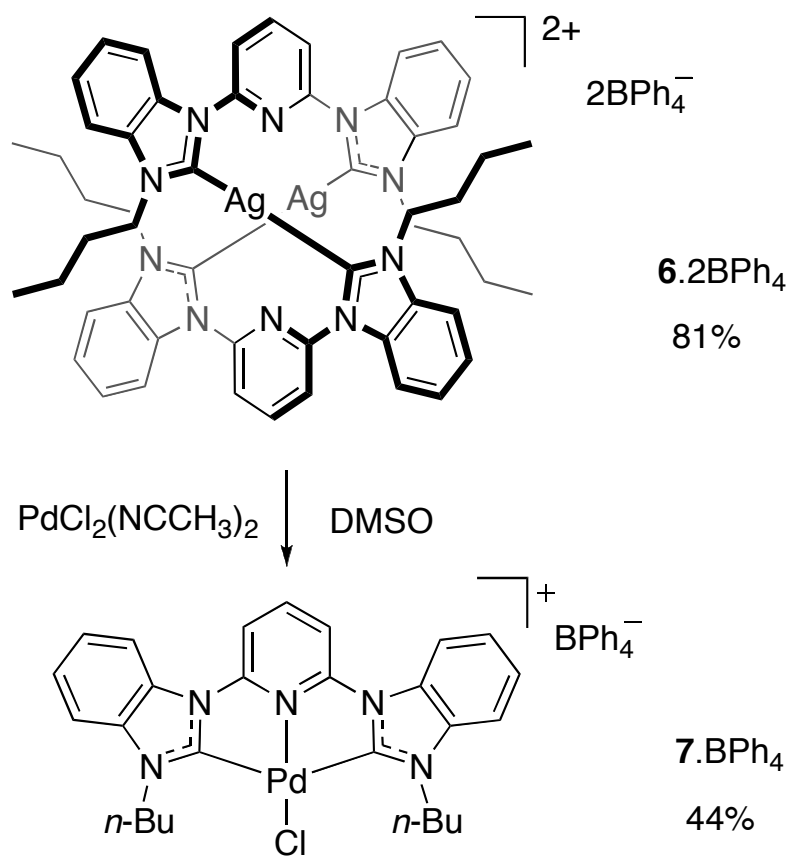


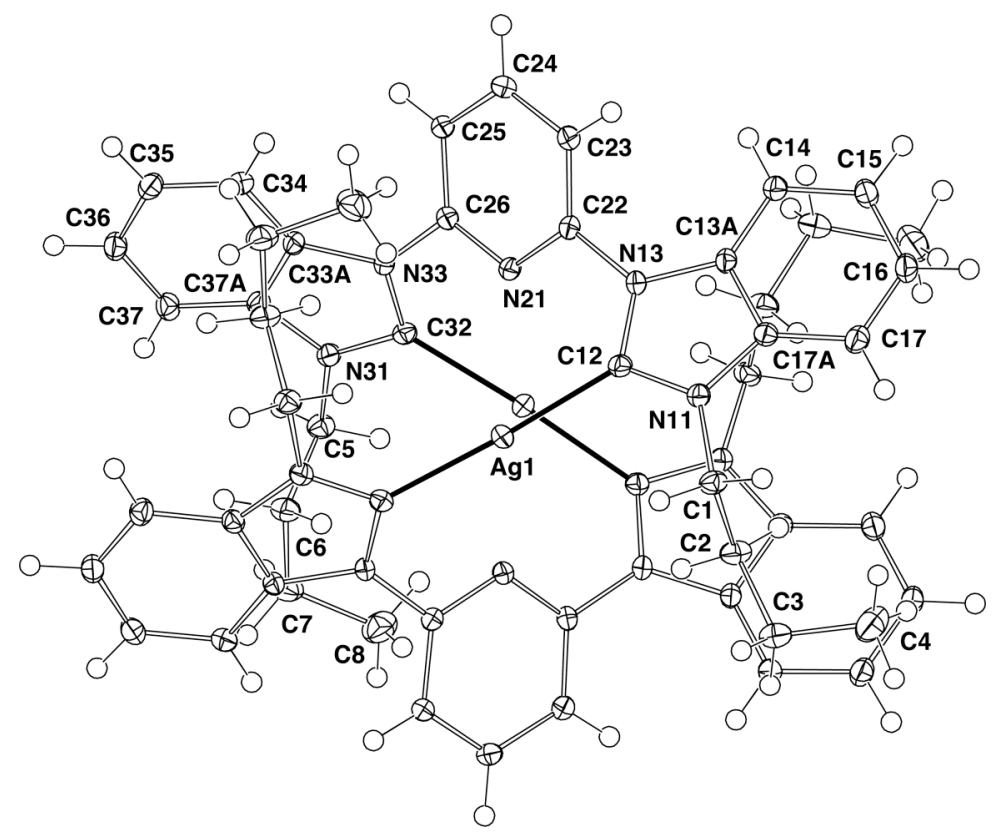

Figure 1. Molecular structure of the cation 6, projected oblique to the Ag-Ag vector. Ellipsoids have been drawn at the 50\% probability level. Selected bond lengths $(\AA)$ and angles (deg): $\operatorname{Ag}(1)-C(12)$ 2.092(1), C(12)- $\mathrm{Ag}(1)-\mathrm{C}(32 ') 176.63(6)$ (' refers to the atom at $-\mathrm{x},-\mathrm{y}, 1-\mathrm{z})$.

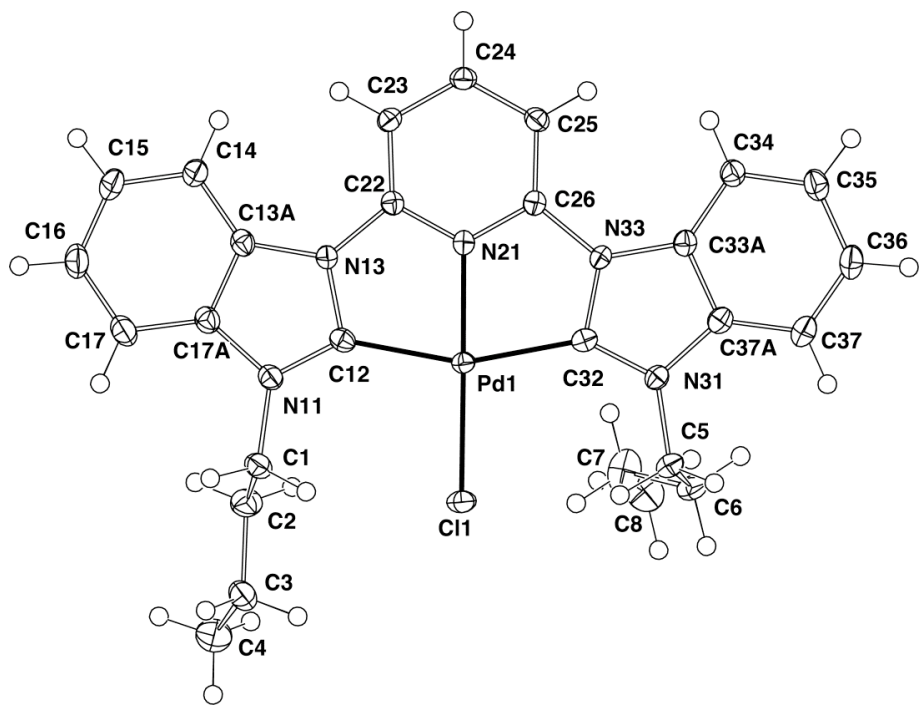

Figure 2. Molecular structure of the cation 7 projected onto the coordination plane. Ellipsoids have been drawn at the 50\% probability level. Selected bond lengths $(\AA)$ and angles (deg): $\operatorname{Pd}(1)-\mathrm{N}(21)$ 1.9701(15), $\mathrm{Pd}(1)-\mathrm{C}(12)$ 2.0202(18), $\mathrm{Pd}(1)-\mathrm{C}(32)$ 2.0280(18), $\mathrm{Pd}(1)-\mathrm{Cl}(1)$ 2.2874(5), $\mathrm{Pd}(1) \ldots \mathrm{Pd}\left(1^{\prime}\right)$ $3.6105(2)$ (' refers to the atom at $1-\mathrm{x}, 1-\mathrm{y}, 1-\mathrm{z}), \mathrm{N}(21)-\mathrm{Pd}(1)-\mathrm{C}(12)$ 79.67(7), $\mathrm{N}(21)-\mathrm{Pd}(1)-\mathrm{C}(32)$ 79.29(6), C(12)-Pd(1)-C(32) 158.94(7), N(21)-Pd(1)-Cl(1) 179.42(4), C(12)-Pd(1)-Cl(1) 99.77(5), $\mathrm{C}(32)-\mathrm{Pd}(1)-\mathrm{Cl}(1) 101.27(5)$. 


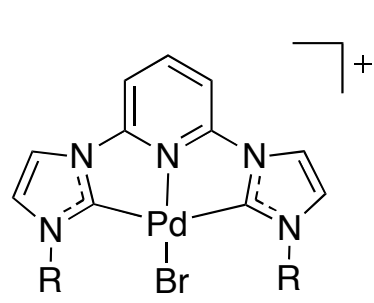

1

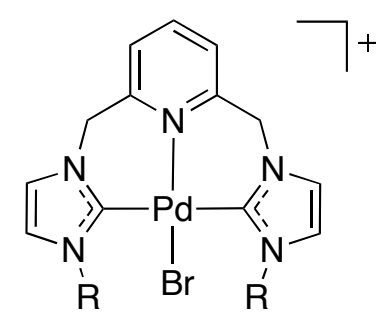

2

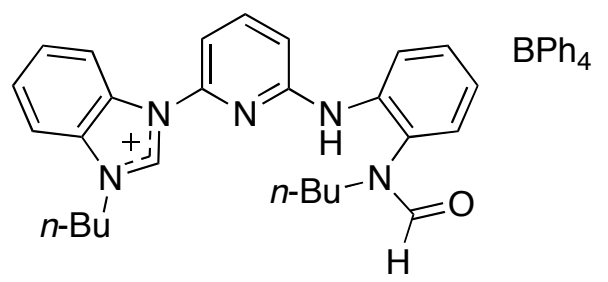

8. $\mathrm{BPh}_{4}$

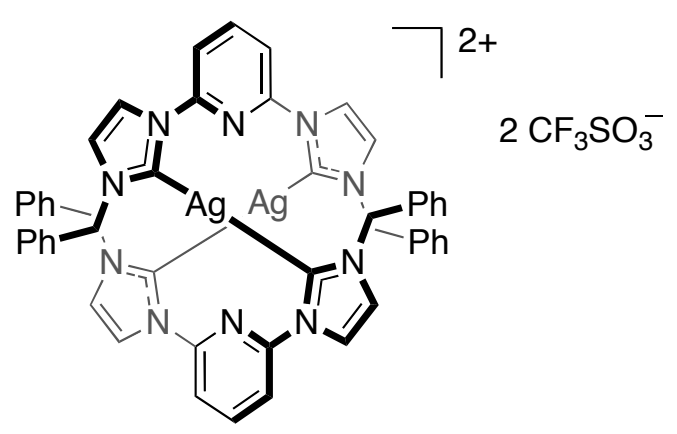

9.2 $\left(\mathrm{OSO}_{2} \mathrm{CF}_{3}\right)$

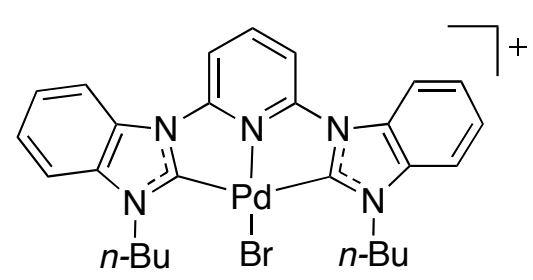

4 


\section{For table of contents use only}

Title: Silver and palladium complexes of a bis(benzimidazolin-2-ylidene)pyridine pincer ligand

Authors: David H. Brown, ${ }^{*}{ }^{\dagger}$ Gareth L. Nealon, ${ }^{\dagger}$ Peter V. Simpson, ${ }^{\ddagger}$ Brian W. Skelton ${ }^{\ddagger}$ and Zhisen Wang ${ }^{\dagger}$

Summary:

The synthesis and characterisation of a dinuclear silver complex bearing a bis(benzimidazolin-2ylidene)pyridne pincer ligand is reported. Transmetallation of the ligand from silver to palladium affords a mononuclear, planar, palladium complex.

TOC graphic
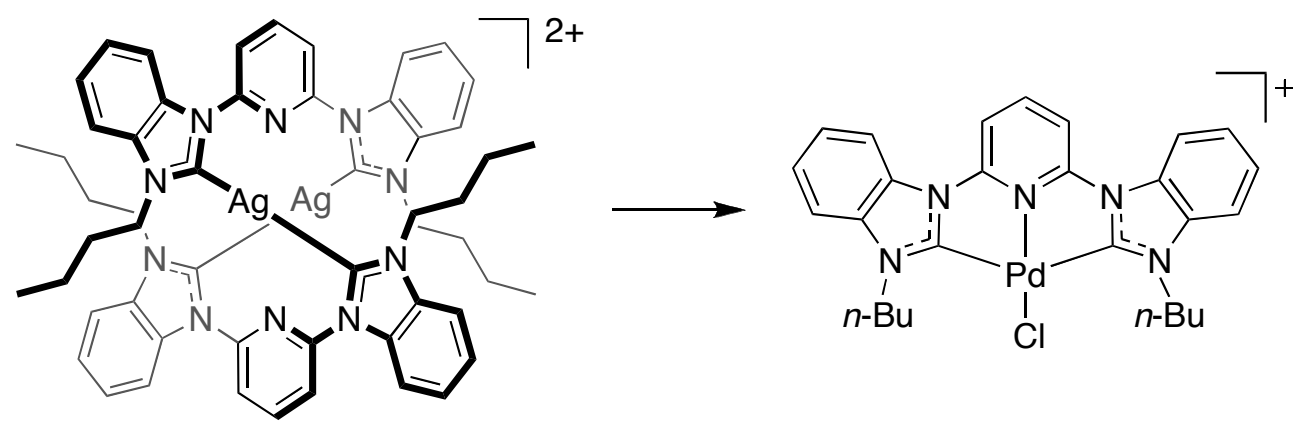


\section{Longer abstract for submission to Chemical Abstracts}

The reaction of sodium benzimidazolate with 2,6-dichloropyridine readily affords 2,6-di(benzimidazol1-yl)pyridine which is alkylated with 1-bromobutane to yield 2,6-bis(3-butylbenzimidazol-1ium)pyridine dibromide. Reaction of the bis(benzimidazolium) salt with silver oxide affords a

dinuclear complexes of the type $\left[\mathrm{L}_{2} \mathrm{Ag}_{2}\right]^{2+}[\mathrm{L}=2$,6-bis(3-butylbenzimidazolin-2-ylidene)pyridine $]$ with a "twisted" structure, which was identified in X-ray crystallographic studies. ${ }^{1} \mathrm{H}$ NMR spectroscopic studies suggest that the dinuclear structure is also present in solution. Transmetallation of the silverNHC complex with $\mathrm{PdCl}_{2}\left(\mathrm{CH}_{3} \mathrm{CN}\right)_{2}$ yields a mononuclear palladium complex of the type $[\mathrm{LPdCl}]^{+}[\mathrm{L}=$ 2,6-bis(3-butylbenzimidazolin-2-ylidene)pyridine], with a chelating C,N,C-pincer ligand. The palladium complex was characterised by NMR spectroscopic and X-ray crystallographic studies. A benzimidazolium-formanilide salt was isolated from the silver oxide reaction, a product of partial hydrolysis of the bis(benzimidazolium) cation, and characterised by NMR spectroscopic and X-ray crystallographic studies. 